\title{
Correction to: Comparative effects of sertraline, haloperidol or olanzapine treatments on ketamine-induced changes in mouse behaviours
}

\author{
O. J. Onaolapo ${ }^{1}$ - T. B. Paul ${ }^{2}$ A. Y. Onaolapo ${ }^{2}$
}

Published online: 2 October 2017

(C) Springer Science+Business Media, LLC 2017

Correction to: Metab Brain Dis (2017) 32:1475-1489

https://doi.org/10.1007/s11011-017-0031-3

In the original publication of the article, occurrences of " $\{\mathrm{F}$ (Becker and Grecksch 2004; Onaolapo et al. 2016b)" should have been " $\{F(5,54)$ " throughout the article.

The online version of the original article can be found at https://oi.org/ 10.1007/s11011-017-0031-3

O. J. Onaolapo olakunleonaolapo@yahoo.co.uk

$\triangle$ A. Y. Onaolapo adegbayibiy@yahoo.com

1 Department of Pharmacology, Ladoke Akintola University of Technology, Osogbo, Osun State, Nigeria

2 Department of Anatomy, Ladoke Akintola University of Technology, Ogbomoso, Oyo State, Nigeria 